\title{
Trzy koncepcje dyskursu: Foucault, Laclau, Habermas
}

\section{KEYWORDS}

Michel Foucault, Ernesto Laclau, Jürgen Habermas, discourse, theory of language, linguistic turn

\begin{abstract}
Rasiński Lotar, Trzy koncepcje dyskursu: Foucault, Laclau, Habermas [Three concepts of discourse: Foucault, Laclau, Habermas]. Kultura - Społeczeństwo - Edukacja nr 2(12) 2017, Poznań 2017, pp. 37-54, Adam Mickiewicz University Press. ISSN 2300-0422. DOI 10.14746/kse.2017.12.2.
\end{abstract}

The aim of this article is to examine three currently dominant concepts of discourse, developed by Michel Foucault, Ernesto Laclau and Jürgen Habermas. I argue that these concepts of discourse constitute neither a coherent methodological agenda nor a coherent theoretical vision. That means that the reference to discourse will always imply engaging with a particular theoretical framework. I briefly discuss the theoretical traditions from which these concepts emerged and point to the essential elements which the respective concepts of discourse derived from these traditions. Concluding, I examine differences between and similarities in the discussed concepts, whereby I address, in particular, the relationship between discourse and everyday language, the notion of subjectivity and the concept of the social world.

\section{Uwagi wstępne: zwrot lingwistyczny}

W dwudziestowiecznej filozofii i teorii języka dzieła de Saussure’a i Wittgensteina odgrywają szczególną rolę. To właśnie sposób myślenia tych autorów stał się impulsem do wprowadzenia problemu języka do nauk społecznych jako zagadnienia podstawowego. Choć obie koncepcje wywodzą się z zupełnie sobie obcych tradycji 
teoretycznych, to właśnie one, rozważane wspólnie, doprowadziły do powstania nowego, dwudziestowiecznego sposobu myślenia o języku, w którym „językowi nie przypisuje się już drugorzędnego znaczenia w naszym pojmowaniu świata, w którym żyjemy, ale znajduje on w nim miejsce zasadnicze" (Harris, 1988: ix). Ów zwrot w myśleniu o świecie społecznym w kategoriach językowych często nazywa się „zwrotem lingwistycznym”. Oznacza on poważne potraktowanie dwóch, pozornie sprzecznych, tez: o niezależności języka (procesu oznaczania) od tradycyjnych nośników znaczenia, takich jak idea (pojęcie) albo przedmiot zmysłowy, oraz o tym, że język jest wytworem społecznym.

Jeśli chodzi o pierwszą tezę, wynika ona z odejścia od klasycznych koncepcji języka opartych na „istotowym” związku pomiędzy nazwą a ideą (Platon, 1990, 383a-b, Leibniz, 2001: 233) lub nazwą a przedmiotem (Locke, 1955: t. 2, III, 2, $\$ 1$, s. 13), zwanych w literaturze reprezentacjonizmem (desygnatywizmem) (Taylor, 2009: 148, 153) lub nomenklaturyzmem (de Saussure, 2002: 77). Obie wersje tej tezy, choć pod wieloma względami odmienne, mają jednak wspólną cechę - wiążą znaczenie z rzeczywistością pozajęzykową, fizyczną lub mentalną. W koncepcji reprezentacjonistycznej, w trójcy: nazwa-idea-przedmiot, nazwa zastępuje albo ideę, albo przedmiot odniesienia dla celów komunikacyjnych. De Saussure uzależnił natomiast znaczenie od miejsca znaku w całym systemie oznaczania (języku). Jeśli porównywać to ujęcie języka z ujęciem klasycznym, sytuacja ulega radykalnemu odwróceniu, gdyż słowa przestają być jedynie „technicznym” dodatkiem do idei lub rzeczy, które „odbijają” rzeczywistość dzięki integrującej roli podmiotu, ale wysuwają się na pierwszy plan w procesie poznania. Język staje się w pewnym stopniu bytem autonomicznym, po pierwsze, wobec podmiotu, po drugie, wobec rzeczywistości, do której się odnosi. De Saussure, podkreślając arbitralność (de Saussure, 2002: 77) związku między elementem znaczącym a elementem znaczonym, stwierdza, że odniesienie do rzeczy ma dla języka drugorzędne znaczenie.

Tej tezy nie można co prawda znaleźć w tak mocnej postaci u Wittgensteina, ale także u niego znajdujemy twierdzenie o uzależnieniu znaczenia od całości (kontekstu) języka: „Znak (zdanie) uzyskuje swoje znaczenie [significance] dzięki systemowi znaków, do którego należy. Mówiąc nieprecyzyjnie: rozumieć zdanie znaczy rozumieć pewien język" (Wittgenstein, 1999: 101). Należy jednak pamiętać, że Wittgenstein kładł większy nacisk na kontekst społeczny wytwarzania znaczenia, o czym świadczy stosowane przez niego pojęcie „gry językowej”, które odnosi się nie tylko do aspektu czysto językowego, ale i „czynności, w które wpleciony jest język” (Wittgenstein, 2000: \$7), do „pewnej działalności, pewnego sposobu życia” (Wittgenstein, 2000: \$23). Pojęcie gry „jest” podstawowym elementem wspólnym koncepcji de Saussure’a i Wittgensteina. Dla obu gra jest pewną kon- 
wencją, zespołem reguł nadających znaczenie swym elementom, przyjętych w ramach pewnej praktyki. Słowo, znak, nabiera więc sensu tylko jako element "gry” poprzez odniesienie do jej pozostałych elementów, to znaczy innych znaków czy słów oraz towarzyszących im reguł, a odniesienie przedmiotowe lub znaczeniotwórcza działalność podmiotu ma znaczenie drugorzędne.

Metafora gry wskazuje więc - z jednej strony - na pewną autonomię języka w stosunku do odniesienia przedmiotowego, które traktowane było tradycyjne jako źródło sensu, z drugiej zaś ukazuje głębokie zakorzenienie języka w świecie społecznym. Wittgenstein posługuje się pojęciem „form (sposobów) życia” (Wittgenstein, 2000: 317) po to, aby ukazać, że język nie podlega jedynie regułom logiki, ale przede wszystkim kształtuje się w ludzkich praktykach. Do pewnego stopnia zgadza się z tym także de Saussure, podkreślając społeczny charakter języka (langue) (de Saussure, 2002: 36), w sensie jego obiektywnego i wspólnego istnienia w umysłach użytkowników języka, dla niego jednak mówienie (parole), jako proces indywidualny i konkretny, jest tylko niedoskonałym odbiciem langue jako bytu abstrakcyjnego i autonomicznego (Jakobson, 2009: 52). Dopiero więc obie tezy - o autonomii języka i jego społecznym charakterze - potraktowane na równi poważnie dają podstawę do zainicjowania procesu zwanego „zwrotem lingwistycznym".

Dla pierwszych rozważań nad „dyskursem”, które pozwoliły otworzyć system języka na to, co stanowiło jego zewnętrze, istotne było zwłaszcza pojęcie "gry”. W swoim tekście, zatytułowanym Struktura, znak i gra w dyskursie nauk humanistycznych, Derrida krytykuje Saussure'owską ideę zamknięcia systemu (jej centrum), ograniczającego swobodną grę znaczeń. Przykładem służą mu prace Lévi-Straussa i wykorzystywane przez niego opozycje bricoleur-inżynier, kultura-natura, które, zdaniem Derridy, pogrążają jego rozważania w myśleniu „centralistycznym”. Według Derridy, dopiero zniknięcie centrum pozwoli pojawić się „dyskursowi”, czyli językowi funkcjonującemu na zasadzie swobodnej gry (Derrida, 2009: 80-82). Metafora gry wskazuje tu wyraźnie na Wittgensteinowski moment, polegający na otwarciu języka na kontekst społeczny. Teza o abstrakcyjności i autonomiczności języka, proponowana przez de Saussure’a, tak atrakcyjna pod względem naukowym, nie uwzględniała żywych i realnych procesów społecznych wpływających na kształtowanie języka i jego praktyki. Trzeba jednak pamiętać, że idea systemowości języka miała daleko idące konsekwencje dla nauk społecznych, gdyż pozwoliła części teoretyków, zwłaszcza spod znaku strukturalizmu, potraktować język jako model świata społecznego, w którym, jak w soczewce, manifestują się praktyki i relacje społeczne - stosunki pokrewieństwa, zwyczaje kulinarne, ideologie, mitologie etc. Praktyki te z powodzeniem były opisywane w pracach 
Lévi-Straussa, Barthesa i Lacana. Język jawił się strukturalistom jako byt samoistny, w którym można było wskazać specyficzne mechanizmy i procesy składające się na wytwarzanie znaczenia, a ponieważ świat społeczny opiera się na procesach oznaczania, język musiał być uznany za konstytutywny element rzeczywistości społecznej. Co więcej, niektórych teoretyków pociągał radykalniejszy argument, powiązany z Saussure’owską koncepcją dwuelementowego znaku, w której o pojęciu (znaczeniu) decydowała arbitralna relacja różnicująca pomiędzy signifiants, głoszący, że funkcjonowanie języka nie polega na dostarczaniu „etykiet” dla obiektywnie istniejących przedmiotów, ale że słowa w danym języku nie tylko artykułują, lecz także kształtują pojęcia i przedmioty właściwe tym językom.

Zastosowane przez Wittgensteina i de Saussure’a pojęcie „gry” pozwala do pewnego stopnia wyjaśnić owe dwa sprzeczne, zdawałoby się, kierunki rozważań. Zarówno Wittgenstein, jak i de Saussure posługują się pojęciem gry, żeby wyjaśnić własne, odmienne od klasycznego, rozumienie gramatyki, które tradycyjnie odwoływało się do pewnej działalności legislacyjnej, często związanej z potwierdzaniem tożsamości i suwerenności narodów europejskich (Harris, 1988: 62). Podejście to, nazywane później „normatywnym”, zakładało, że skodyfikowane reguły gramatyki były podstawą właściwego użycia języka. Oznaczało to, że pewne praktyki językowe, pomimo że utarte, niekoniecznie musiały automatycznie kwalifikować się jako gramatyczne, gdy nie odpowiadały skodyfikowanym regułom. Natomiast Wittgenstein i de Saussure, objaśniając, czym jest dla nich gramatyka, odwołują się do pojęcia gry. Dla Wittgensteina stosunek gramatyki do języka jest taki sam jak opis (reguł) gry do samej gry (Wittgenstein, 1974: 60). Władanie jakimś językiem nie polega zatem na umiejętności wyjaśnienia jego reguł gramatycznych, ale na mówieniu nim, zdolnością komunikowania się z innymi. Podobnie, opanowanie gry w tenisa nie polega na tym, że potrafimy precyzyjnie wyłożyć jego wszystkie reguły, ale na tym, że potrafimy właściwie posługiwać się rakietą na korcie (Wittgenstein, 1974: 62).

W podejściu tym reguły gry lub reguły gramatyki są czymś właściwym samej grze lub gramatyce, nie służą one żadnym celom spoza gry lub języka. Oznacza to, że gramatyka, tak jak reguły jakiejkolwiek gry, są czymś arbitralnym, ale i autonomicznym. Gramatyka jest pewną konwencją opartą na rzeczywistych praktykach posługiwania się słowami. Jeśli nagle zaczynam posługiwać się jakimś słowem w niekonwencjonalny sposób, nie oznacza to, że mówię niepoprawnie, ale że mówię coś innego, tak jak zmiana reguł gry w szachy w trakcie gry oznacza przejście do innej gry, a nie złą grę - dopóki w praktyce tego typu ruchy są możliwe, nie ma powodu, by oceniać użycie reguł według ich przystawalności do jakiegoś abstrakcyjnego wzorca. Zwłaszcza że ta ocena również musiałaby podlegać pewnym 
regułom gramatyki, to znaczy, wszystko to, co da się wyjaśnić, ocenić, uzasadnić, może być wyjaśnione, ocenione i uzasadnione w języku, co oznacza, że samego języka nie da się wyjaśnić, ocenić czy uzasadnić. Dlatego Wittgenstein powiada, że „gramatyka nie musi odpowiadać jakiejkolwiek rzeczywistości. To reguły gramatyczne określają znaczenie (konstytuują je), a zatem same nie odpowiadają żadnemu znaczeniu i w tym sensie są arbitralne" (Wittgenstein, 1974: 184). W tym też znaczeniu można powiedzieć, że język może być więc zarazem czymś głęboko społecznym, gdyż to praktyka, formy życia decydują o regułach jego użycia, ale zarazem czymś autonomicznym, gdyż nie podporządkowuje się żadnym regułom zewnętrznym wobec niego samego.

Dopiero te dwie cechy języka ujęte wspólnie pozwoliły zapoczątkować rozważania nad dyskursem, które wszakże prowadzono w różnych, często wyraźnie sprzecznych, perspektywach teoretycznych. Trzy, jak sądzę, obecnie najbardziej wpływowe podejścia do dyskursu znajdujemy u Foucaulta, Habermasa i Laclau.

\section{Tradycje teoretyczne}

\section{Foucault}

Jak wiadomo, Foucault, z jednej strony, bardzo niechętnie przyznawał się do swoich inspiracji teoretycznych, z drugiej zaś znany był z tego, że lubił konstruować czy upiększać własną drogę intelektualną (Foucault, 2000b). Powszechne było przyczepianie mu etykiet, które niezmiernie go irytowały - strukturalisty, poststrukturalisty, kryptomarksisty czy postmodernisty, albo przedstawianie go jako teoretyka społecznego, literata czy teoretyka literatury spod znaku transgresji, psychologa lub socjologa. W La vie, l'experience et la science, w jednym z niewielu tekstów, w którym próbuje rekonstruować własną drogę teoretyczną, Foucault wprowadza rozróżnienie pomiędzy filozofią „wiedzy, racjonalności i pojęcia” a filozofią „doświadczenia, sensu i podmiotu” (Foucault, 2000c: 187). Rozróżnienie to pochodzi od reakcji na wykłady Husserla w Paryżu w 1929 roku, w której można wyróżnić dwie interpretacje - Sartre’a w stronę hermeneutyki i filozofii egzystencji (Heidegger), kontynuowaną później przez Merleau-Ponty’ego, która potem doprowadziła do rywalizacji i rozmaitych związków pomiędzy strukturalizmem, fenomenologią i marksizmem, oraz Cavaillesa - który zastosuje fenomenologię Husserla do filozofii matematyki, a następnie jego myśl zostanie rozwinięta, względnie niezależnie od fenomenologii Husserla, przez Canguilhema i Bachelarda, tworząc coś, co Foucault nazywa „filozofią pojęcia”, w ramach specyficznej epistemologicznej historii nauki. 
Foucault wpisuje się zdecydowanie w tradycję "filozofii pojęcia” (Foucault, 2000b: 299). Głównym problemem historii epistemologicznej w wersji Bachelarda i Canguilhema była racjonalność. Zdaniem Bachelarda najwyższym przejawem ludzkiej racjonalności jest nauka, a zatem badanie pojęć naukowych jest zarazem najlepszym źródłem wiedzy o ludzkiej racjonalności. W owych badaniach najważniejsze są dwie kwestie: zdaniem Bachelarda, który opiera swoje rozumienie historii na pojęciu „rekurencji”" ${ }^{1}$, każda historyczna refleksja nad nauką musi być normatywna i uwzględniać teraźniejszy stan rozwoju nauki. Koncepcja ta odrzuca spojrzenie na historię nauki z perspektywy czasu kosmicznego i posługuje się takimi pojęciami jak „błąd”, „przeszkoda epistemologiczna”, „zerwanie” (zob. np. Bachelard, 2002: 22) etc. Druga kwestia dotyczy problemu racjonalności. Z dzisiejszej perspektywy możemy ocenić błędy i postęp racjonalności, a także wskazać, że ludzka racjonalność nie ma monolitycznego charakteru, ale składa się raczej $\mathrm{z}$ różnych „obszarów racjonalności” (les régions rationelles) (zob. np. Bachelard, 1949: r. 7). Te dwie konsekwencje badań w ramach historii epistemologicznej odgrywają niezwykle ważną rolę u Foucaulta. Jego refleksję także można nazwać z powodzeniem historią racjonalności, ale racjonalności badanej w perspektywie innych nauk, które Foucault nazywał humanistycznymi (psychiatria, psychologia, medycyna, biologia, językoznawstwo, ekonomia, prawo). Takie „błędy” czy „przeszkody" w historii nowoczesnej racjonalności to z pewnością szaleństwo, ale także choroba, występek, zbrodnia, seksualność, czyli tematy, które Foucault porusza w swoich kolejnych pracach.

Drugim ważnym źródłem koncepcji Foucaulta jest z pewnością filozofia Nietzschego, a zwłaszcza jego idea genealogii, w której uwzględnia społeczny czy polityczny wymiar moralności, a swoje analizy historyczne określa jako poszukiwanie "pochodzenia” pojęć, w przeciwieństwie do poszukiwania „źródła”, co uwzględnia rolę cielesności i wpływów politycznych (władzy) w badaniu pojęć naukowych i moralnych (Foucault, 2000a). Zarówno idea historyczności pojęć naukowych, pluralizmu racjonalności, jak i analizy zdarzeń historycznych z uwzględnieniem wpływów władzy i otoczenia instytucjonalnego będą miały istotny wpływ na Foucaultowskie rozumienie dyskursu.

\section{Habermas}

Jeśli chodzi o Habermasa, to jego koncepcja jest chyba ostatnią wielką syntezą współczesnej filozofii. I to syntezą pod każdym względem, bo uwzględniającą zarówno tradycję myśli kontynentalnej, jak i analitycznej. Zastrzegam jednak,

\footnotetext{
${ }^{1}$ Pojęcia tego używa Canguilhem, powołując się na Bachelarda, zob. Canguilhem, 1957: 166.
} 
że będę się tu zajmował zapleczem teoretycznym jego koncepcji, które jest ważne z punktu widzenia rozumienia dyskursu, a nie wszystkimi inspiracjami teoretycznymi Habermasa.

Pierwszym źródłem koncepcji dyskursu Habermasa jest transcendentalizm Kantowski, polegający na skierowaniu analiz filozoficznych nie na przedmioty empiryczne, ale na „warunki ich możliwości”. Ten moment Kantowski jest w zasadzie obecny we wszystkich koncepcjach dyskursu. Laclau wprost wpisuje swoją teorię dyskursu w tradycję transcendentalną w filozofii (Laclau, 1998: 155), a Foucault posługuje się pojęciem archiwum (Foucault, 1977: 165) oraz historycznego a priori (Foucault, 1977: 162). Oczywiście to drugie pojęcie sygnalizuje jednocześnie poważne odstępstwo od projektu transcendentalizmu Kantowskiego, co jest charakterystyczne nie tylko dla Foucaulta, ale i Laclau. Historyczność a priori jest z pewnością dla Foucaulta konsekwencją przyjęcia historystycznego stanowiska Bachelarda i Canguilhema. Dla Kanta warunki możliwości poznania przedmiotu były czymś transcendentalnym i powszechnym, możliwym do zastosowania w poznaniu wszelkich możliwych przedmiotów. Właśnie ten wątek rozwinął Habermas, dla którego zobowiązania podjęte w ramach dyskursu mają uniwersalną ważność (Habermas, 2015: 19). W tym kontekście szczególnie ważnym motywem Kantowskim u Habermasa jest idea autonomii wolnej woli fundującej moralność, wyrażającej się w imperatywie kategorycznym. Ta Kantowska zasada jest uniwersalna, ponieważ jest wyrazem ludzkiej wolności i rozumu, który sam nakłada na siebie ograniczenia formalne, a zatem musi się im podporządkować. Jest to więc wyraz autonomii człowieka, a nie podporządkowania się zewnętrznej regule (heteronomii). Motywy te są szczególnie wyraźne w ostatnich pracach Habermasa, gdzie wprowadza do swych rozważań na temat dyskursu tak zwaną „zasadę uniwersalizacji” i „zasadę dyskursu”, o których szerzej piszę w kolejnym podrozdziale.

Drugim wątkiem ważnym u Habermasa jest przekonanie o kontraktualnym charakterze społeczeństwa, co czyni go spadkobiercą takich myślicieli jak Hobbes, Locke, Rousseau czy Kant, wiążąc jego myśl w głównej mierze z szeroko pojętym liberalizmem. Umowa społeczna w tych koncepcjach ma zarazem charakter eksplanacyjny, jak i legitymizujący, to znaczy z jednej strony wyjaśnia genezę wspólnoty politycznej, z drugiej zaś wskazuje na uzasadnienie autorytetu władzy (legitymizację), głosząc, że pierwotnym aktem założycielskim każdego społeczeństwa jest zgoda czy umowa zawarta przez obywateli. W tradycji tej ów akt ma charakter hipotetyczny i regulatywny. Podobnie u Habermasa funkcjonuje pojęcie „sytuacji idealnej rozmowy" (Habermas, 1983: 43; por. Habermas, 2004: 39), będącej kontrfaktyczną formą komunikacji, zakładającej pewną idealizację. Jej celem jest 
natomiast wprowadzenie podstawy krytyki zniekształceń czy odstępstw od ideału racjonalnego.

Jeśli chodzi o analityczną koncepcję języka, Habermas czerpie tu z kilku źródeł. Najważniejsze wydają się: koncepcja aktów mowy Austina oraz rozróżnienie na akty illokucyjne i perlokucyjne (Austin, 1993: 692; por. Habermas, 2000a: 483), a także pojęcie kierowania się regułą Wittgensteina (Wittgenstein, 2000: \$185-\$242). Pojęcie illokucji pozwala Habermasowi przyjąć tezę o pierwotności komunikacyjnych użyć języka w stosunku do użyć instrumentalnych czy strategicznych (Habermas, 2000a: 477), natomiast odwołanie do Wittgensteina koncepcji kierowania się regułą pozwala mu na uzasadnienie intersubiektywności działań społecznych (tzw. argument języka prywatnego) (Habermas, 2000a: 30).

\section{Laclau}

U Ernesta Laclau można wskazać trzy inspiracje teoretyczne, którymi posłużył się w swojej „teorii dyskursu”. Przede wszystkim jest to pewien specyficzny, antyekonomistyczny nurt w obrębie marksizmu, łączony najczęściej z Antoniem Gramscim i jego koncepcją hegemonii. Istotą hegemonii jest dla Gramsciego przygodność, w odróżnieniu od zakładanej przez Marksa konieczności i nieuchronności procesu dziejowego, zmierzającego do komunizmu w wyniku sprzeczności obecnych wewnątrz samego kapitalizmu. Była to zatem ucieczka od redukcjonizmu ekonomicznego obecnego szczególnie w późniejszej fazie twórczości Marksa. Owe elementy „przygodne”, na które wskazywali na przykład Kautsky, Bernstein czy Sorel, to między innymi rola intelektualistów w procesie dziejowym czy idea strajku generalnego (Laclau, Mouffe, 2007: r. 1). To całkowicie zmieniało spojrzenie na politykę, a także na idee podmiotu zmiany historycznej. Dla Gramsciego hegemonia była procesem tworzenia nowej tożsamości zbiorowej, w przeciwieństwie do idei marksistowskiej, w której uprzywilejowaną pozycję ma proletariat (podmiot rewolucji jest $\mathrm{z}$ góry określony). Hegemonia zależy więc nie od pozycji w stosunkach produkcji, ale od działań czysto politycznych w obrębie państwa i społeczeństwa obywatelskiego. Podstawowym warunkiem przejęcia władzy staje się dla Gramsciego zdobycie hegemonii, czyli moralnego i intelektualnego przywództwa w społeczeństwie (Gramsci, 1961: 517), czego nie da się osiągnąć przemocą, ale poprzez zgodę - jest to więc demokratyczna wersja marksizmu.

Drugą inspiracją Laclau są strukturalistyczne koncepcje języka. Odwołuje się on przede wszystkim do koncepcji de Saussure’a, Althussera i Derridy. Ogólnie rzecz biorąc, wspólną cechą tych podejść jest idea systemowości języka, to znaczy założenie, że język jest pewną całością, „systemem różnic”, względnie niezależną od rzeczywistości pozajęzykowej. Jak już pisałem wcześniej, oznacza 
to, że znaki (znaczące) mogą coś oznaczać, niekoniecznie odnosząc się do zewnętrznych przedmiotów, ale uzyskują znaczenie poprzez relację z innymi znakami. Duże znaczenie ma dla niego w tym kontekście krytyka strukturalistycznej idei zamknięcia systemu przeprowadzona przez Derridę, nawołującego do postrzegania dyskursu w kategoriach „otwartości” czy niemożliwości domknięcia systemu. To także zdawała się wyrażać idea „naddeterminacji” Althussera (Althusser, 2009: 113-156), zapożyczona przez niego od Freuda, która zakładała „względną autonomię" nadbudowy wobec bazy. W tym kontekście niezwykle ważne znaczenie ma także odniesienie do Lacanowskich analiz podmiotowości, zakładających niemożliwość pełnej identyfikacji podmiotu, polegającą na nieskończonym procesie identyfikacji powodowanym przez „nieobecność” realnego (Stavrakakis, 1999: 27). Laclau posługuje się pojęciem "punktu węzłowego” zapożyczonego od Lacana, który oznacza częściową stabilizację znaczenia. Owa możliwość częściowej stabilizacji znaczenia jest według niego warunkiem zmiany znaczenia (Laclau, Mouffe, 1990: 120).

Można podsumować tę część, odnosząc się do dyskusji pomiędzy Habermasem a Foucaultem, która co prawda nigdy nie doszła do skutku, ale w rozmaity sposób była później rekonstruowana (zob. Kelly, 1994; Ashenden, Owen, 1999), a która ukazuje w jaskrawy sposób metodologiczne różnice pomiędzy ich podejściami. Foucault wypowiadał się kilkakrotnie w kurtuazyjny sposób na temat szkoły frankfurckiej (Foucault, 2000b: 302), podkreślając przede wszystkim jej podobieństwa z własną koncepcją, nigdy jednak na poważnie nie zajął się myślą Habermasa. Natomiast Habermas poddał ostrej krytyce koncepcję Foucaulta w Filozoficznym dyskursie nowoczesności (Habermas, 2000b). Przedmiotem tego wirtualnego sporu była kwestia możliwości krytyki. Pytanie, które postawił Habermas, można w zasadzie streścić następująco: Czy możliwa jest krytyka programowo pozbawiona podstaw normatywnych? Habermas stwierdził, że uprawianie krytyki musi zakładać odniesienie do pewnego normatywnego ideału, będącego wyrazem ludzkiej racjonalności, w tym przypadku racjonalności komunikacyjnej wyrażanej właśnie w dyskursie. Dlatego wszelkie próby krytyki genealogicznej/ archeologicznej Foucaulta muszą, chcąc czy nie chcąc, zawierać pewien element normatywny, z czego wywnioskował, że Foucault jest kryptonormatywistą - to znaczy przemyca pewien normatywizm, na przykład ideał wolności, jednocześnie się jednak do tego nie przyznając. Odpowiedź Foucaulta trzeba by tu oczywiście rekonstruować, pewne jest jednak, że nie uznawał on żadnej uprzywilejowanej, uniwersalnej pozycji w tym, co społeczne/polityczne, która pozwalałaby uzasadnić ostatecznie krytykę. Wydaje mi się, że Foucaulta - ze względu na inspiracje, które czerpie z francuskiej filozofii nauki - interesuje coś zupełnie innego: mianowicie 
ukazywanie wszelkich form dominacji i wykluczenia, jakie w perspektywie historycznej towarzyszyły ludzkości, ze szczególnym uwzględnieniem roli nauki w powiązaniu z władzą. Dyskurs nie jest zatem normatywną podstawą krytyki, ale narzędziem analizy historycznej. Jego cel jest niezwykle praktyczny - poprzez ukazanie przygodności i historycznej genezy pewnych pojęć i rozróżnień (na przykład pojęcia szaleństwa) Foucault pragnie przyczynić się do zmniejszenia dominacji, co można by nazwać „skromną emancypacją”, choć pojmowaną w zupełnie inny sposób niż u Marksa czy Habermasa. Dla niego emancypacja nie byłaby więc realizacją źródłowej racjonalności człowieka, gdyż, jak wiemy od Bachelarda i Canguilhema, racjonalność ludzka jest czymś historycznym i niejednolitym, ale raczej „poszerzeniem przestrzeni wolności” (Foucault, 2000b: 313), „wolności konkretnej” (Foucault, 2000b: 313), w konkretnej dziedzinie i w konkretnym obszarze ludzkiej działalności.

\section{Rozumienie dyskursu}

W tej części zajmę się szkicowym przedstawieniem tytułowych koncepcji dyskursu, które uwzględni wszakże jedynie kluczowe w moim przekonaniu ich elementy. Będę kładł nacisk głównie na motywy, które w wyraźny sposób ukazują, jak dana koncepcja wpisuje się w określoną formację teoretyczną, powiązaną zwłaszcza z pewnymi wyborami metodologicznymi, rozumieniem przedmiotu badań czy celu podejmowanych analiz.

\section{Foucault}

Dla niniejszych rozważań najważniejszą rolę odgrywają trzy kluczowe dla koncepcji dyskursu Foucaulta pojęcia: „formacji dyskursywnej”, „archiwum” i „praktyki dyskursywnej".

Formacja dyskursywna to system rozproszonych wypowiedzi, w którym analityk dyskursu rozpoznaje regularność (Foucault, 1977: 199). Jest to bardzo ważna teza, gdyż tutaj ujawnia się różnica pomiędzy podejściem Foucaulta a strukturalizmem. Formacja nie jest strukturą leżącą u podstaw lub ukrytą pod „wypowiedziami” (énoncés) (Foucault, 1977: 142), do której można dotrzeć poprzez hermeneutyczną interpretację. Formację tworzą rzeczywiste wypowiedzi („zdarzenia dyskursywne") w swym rozproszeniu i naturalnej regularności, którą uchwycić może dopiero archeolog. Zakłada to również możliwość transformacji dyskursu, co polegałoby na dostrzeżeniu innych związków, innych regularności w rozproszeniu dyskursu (Andersen, 2003: 13-14). 
Dostrzeżenie regularności w rozproszeniu pozwala archeologowi zrekonstruować archiwum (Foucault, 1977: 165), będącym czymś w rodzaju pola przekształceń wypowiedzi, czy też „historycznym a priori” (Foucault, 1977: 162) danego zdarzenia dyskursywnego. Archiwum decyduje o tym, jakie wypowiedzi mogły się „wydarzyć”, a jakie zostawały zepchnięte na margines jako błędne, odrzucane; jest pewnym warunkiem możliwości pojawienia się tych wypowiedzi, które rzeczywiście wystąpiły. Archiwum nie ma jednak charakteru transcendentalnego, jak u Kanta, ale historyczny i tymczasowy. Foucault posługuje się tu pojęciem „pozytywności” (Foucault, 1977: 160). Oznacza to, że warunki możliwości pojawienia się wypowiedzi można zbadać jedynie a posteriori, w innym przypadku mielibyśmy do czynienia ze spekulacją lub z metafizyką. Na przykład Foucaultowskie analizy szaleństwa, narodzin medycyny czy nowoczesnego więziennictwa są w dużej mierze próbą uchwycenia historycznych warunków możliwości czegoś, co można nazwać dzisiejszą racjonalnością, tzn. tego, co doprowadziło nas, że myślimy dziś o sobie i o świecie tak, a nie inaczej. Uchwycenie warunków możliwości własnego sposobu myślenia zakłada pewien moment przygodności, gdyż wynika stąd, że to, jak myślimy, jest wynikiem splotu okoliczności, który mógł się potoczyć zupełnie inaczej. W jednym z późnych tekstów Foucault określa swoje podejście krytyczne jako „sztukę unikania rządzenia w obecny sposób” (Foucault, 1990: 38). Oznacza to, że Foucaultowska „skromna emancypacja" nie jest skierowana na pełne wyzwolenie ludzkości, ale raczej na poszukiwanie takiego modelu rządzenia, który ograniczałby dominację w największym stopniu.

Z archiwum ściśle związane jest pojęcie praktyk dyskursywnych. Określenie praktyk dyskursywnych jest właściwie tożsame z określeniem samego dyskursu, który Foucault rozumie właśnie jako pewną praktykę, czyli postępowanie według reguł, by odwołać się tu do terminu Wittgensteina. Foucault definiuje praktyki dyskursywne jako pewne „anonimowe reguły” tworzenia wypowiedzi, które można dość precyzyjnie określić i które nie są efektem jakichś zewnętrznych wobec dyskursu czynników, ale pewnej praktyki właściwej samemu dyskursowi. W Archeologii wiedzy określa je jako „zbiór anonimowych, historycznych, zawsze określonych w czasie i przestrzeni reguł, które determinowały w danej epoce i dla danego obszaru społecznego, ekonomicznego, geograficznego lub językowego warunki działania funkcji wypowiedzeniowej" (Foucault, 1977: 151). Należy jednak pamiętać, że oprócz tych czysto językowych reguł tworzenia wypowiedzi Foucault podkreślał także rolę praktyk niedyskursywnych (np. procesy ekonomiczne, polityczne i instytucjonalne) (Foucault, 1977: 101) wpływających na formację dyskursywną, które nazywa „zależnościami pozadyskursywnymi” (Foucault, 1994: 680). 
Jak stwierdza: „autonomia dyskursu i jego specyfika nie nadają mu wcale statusu czystej idealności i całkowitej niezależności historycznej" (Foucault, 1977: 202). Ten ostatni argument spotkał się później z dość powszechną krytyką.

\section{Laclau}

Jeśli mielibyśmy powyższe założenia Foucaultowskiej analizy dyskursu odnieść do koncepcji Laclau, to w zasadzie można powiedzieć, że w całości przejmuje on pojęcie formacji dyskursywnej Foucaulta jako regularności w rozproszeniu (Laclau, Mouffe, 2007: 112). Laclau nie przyjmuje natomiast rozróżnienia na praktyki dyskursywne i niedyskursywne, które wprowadza Foucault, gdyż są to dla niego po prostu różne aspekty praktyki społecznej (lingwistyczne i behawioralne), które obejmują "praktyki artykulacji” (articulation) (Laclau, Mouffe, 2007: 111), rozumiane jako procesy tworzenia punktów węzłowych częściowo stabilizujących znaczenie (Laclau, Mouffe, 2007: 113). A zatem można powiedzieć, że dla Laclau istnieją jedynie praktyki dyskursywne, które rozumie on jako praktyki artykulacji. Nie znaczy to jednak bynajmniej, że dla Laclau nie istnieją przedmioty fizyczne, poza dyskursem, oznacza to tylko, że każdy przedmiot konstruowany jest jako przedmiot dyskursu, to znaczy przedmioty fizyczne istnieją realnie i niezależnie od naszej woli, ale w momencie, gdy przypisuje się im jakieś znaczenie, stają się one elementami dyskursu (Laclau, Mouffe, 1990: 101). W tym sensie w zasadzie wszystko staje się dyskursem, o ile staje się przedmiotem procesu oznaczania.

Ważnym pojęciem Laclau wprowadzonym w późniejszych pracach jest pojęcie „pustego znaczącego”. Oznacza ono, najprościej rzecz biorąc, znaczące bez znaczonego, czyli takie znaczące, które służy do oznaczenia tego, co niemożliwe do oznaczenia (Laclau, 1996: 37). Takie „rozluźnienie” znaczenia następuje w sytuacjach, gdy jakaś tworząca się tożsamość polityczna usiłuje definiować własną specyfikę poprzez odróżnienie się od zagrażającego jej zewnętrza jako czystego zaprzeczenia niej samej. Wówczas pewne elementy znaczące tracą swoje znaczenie (stają się sobie równoważne - wchodzą w „logikę równoważności” - Laclau, Mouffe, 2007: 140) i następuje hegemoniczna walka, by jedno z nich zajęło miejsce reprezentujące wszystkie związane z sobą tożsamości. Aby to było możliwe, musi ono stracić swoje specyficzne znaczenie, czyli w pewnym sensie stać się „pustym”, by móc objąć możliwie szerokie pole znaczeń. Przykładem może być mit zagrożonego narodu, który jest w stanie zgromadzić pod sobą zupełnie różne siły i grupy społeczne. Jak dobrze może oddziaływać puste znaczące, pokazują ostatnie wydarzenia w Polsce, gdzie na naszych oczach dokonuje się tego typu zawłaszczenie pojęcia narodu i patriotyzmu. 
Można powiedzieć, że koncepcja Laclau jest bliska Foucaultowskiej wizji dyskursu, jednakże problemem staje się kontekst i cel, jakiemu służy analiza dyskursu w każdym z przypadków. Jeśli Foucault stara się badać dyskurs jako formę przejawiania się wiedzy i jej związków z władzą, Laclau widzi dyskurs jako bezpośrednią arenę walki hegemonicznej o nadawanie znaczeń, w której konstruuje się także tożsamość podmiotu. Wspólnym wymiarem obu podejść jest na pewno brak refleksji normatywnej oraz wymiar emancypacyjny tych koncepcji, choć w każdym przypadku inaczej definiowany.

\section{Habermas}

Habermas w zasadzie nie definiuje nigdzie własnego pojęcia dyskursu, to znaczy nie zajmuje się nim jako takim, ale raczej omawia go, można powiedzieć, w kontekście innych rozważań, zazwyczaj dotyczących uzasadnienia norm moralnych czy decyzji politycznych podejmowanych w ramach deliberacji. Podkreśla praktyczny wymiar dyskursu, co odzwierciedla się także w nazewnictwie, gdyż posługuje się zazwyczaj pojęciami „etyka dyskursu” lub „dyskurs praktyczny”. Z drugiej strony Habermas przyznaje jednak, że zasady dyskursu mają charakter formalny, idealizacyjny i kontrfaktyczny, co jest z kolei uzasadnieniem uniwersalności rozstrzygnięć osiągniętych w ramach dyskursu.

Habermas opiera swoje rozumienie dyskursu na teorii działania komunikacyjnego. Jej istotą jest założenie, że oprócz wyróżnianych przez Webera typów działań zorientowanych na cel (charakterystycznych dla racjonalności instrumentalnej) istnieją także działania komunikacyjne, polegające na procesach dochodzenia do porozumienia poprzez „wspólne definiowanie sytuacji” (Habermas, 1990: 468). Zdaniem Habermasa nie da się ich zredukować do działań instrumentalnych, a co więcej, pełnią one wobec tych pierwszych nadrzędną funkcję. Jak już wspomniałem, Habermas dochodzi do takiego wniosku na podstawie analizy koncepcji aktów illokucyjnych i perlokucyjnych Austina, która dowodzi, że aby wypowiedź mogła stać się działaniem zorientowanym na rezultat, najpierw musi stać się działaniem komunikacyjnym, to znaczy najpierw musi zostać zrozumiana. Habermas stwierdza zatem, że użycie języka zorientowane na porozumienie jest pierwotnym użyciem języka, względem którego inne, instrumentalne użycia, zachowują się pasożytniczo (Habermas, 1990: 477). Model działania oparty na komunikacji i porozumieniu jest więc dla niego pewnym punktem odniesienia dla wszelkich działań społecznych, które powinny uwzględniać naturalne dążenie człowieka do zgody.

Aby jednak oprzeć życie społeczne na działaniu komunikacyjnym, potrzebne jest, zdaniem Habermasa, istnienie czegoś, co nazywa „etyką dyskursu”. Nasza „codzienna praktyka komunikacyjna”, która oparta jest na oczywistościach i zwy- 
czajach (Habermas, 1982: 272), nie może zapewnić tego, że będziemy koordynować swoje działania, opierając je na porozumieniu, czyli zapewnić ich racjonalność. Dlatego należy wyjść poza codzienność poprzez krytyczne badanie naszej codziennej komunikacji - oznacza to, że musimy poddać krytycznemu osądowi wszystkie pewniki i oczywistości naszej codziennej wiedzy. Częścią dyskursu mogą stać się tylko te pojęcia i przekonania, które zostały poddane procedurze uzasadnienia i argumentacji, tylko wówczas osiągnięte porozumienie będzie miało charakter racjonalny i uniwersalny. Aby jednak nasz język mógł stać się dyskursem, należy spełnić następujące warunki:

Każdy podmiot mający zdolność mówienia i działania może wziąć udział w dyskursie.

Każdemu wolno kwestionować wszelkie twierdzenia.

Każdemu wolno wnieść do dyskursu jakiekolwiek twierdzenie.

Każdy może wyrażać swe postawy, pragnienia i potrzeby.

Nikomu nie można zabronić, poprzez wewnętrzny lub zewnętrzny przymus, egzekwowania swych praw w sposób, jaki określono. (Habermas, 2015a: 89)

$\mathrm{W}$ dyskursie nie ma zatem mowy o wykluczaniu kogokolwiek $\mathrm{z}$ dyskusji, przedkładaniu jakichś głosów nad inne, o próbach manipulacji czy przymuszania kogoś do przyjęcia którejś z argumentacji. Nie ma w nim żadnych ograniczeń poza „przymusem lepszego argumentu”. Warunki te są czysto formalne i jeśli zostaną spełnione, nasze sądy będą mogły być uznane za racjonalne i powszechne w myśl zasady uniwersalizacji (U) i zasady dyskursu (D) (Habermas, 2015b: 272). (U) mówi mniej więcej tyle, że każdy w nieprzymuszony sposób musi przyjąć wszelkie przewidywane konsekwencje wprowadzanej normy. (D) natomiast głosi, że każda uprawomocniona norma zostałaby przyjęta przez wszystkich zainteresowanych, gdyby mogli uczestniczyć w „dyskursie praktycznym”.

Podsumowując koncepcję dyskursu Habermasa, chciałbym posłużyć się przykładem (Tully, 2008: 51). Wyobraźmy sobie, że ktoś pragnie podważyć moje roszczenie ważnościowe do prawdziwości (i szczerości), podając w wątpliwość moją tożsamość w trakcie konferencji naukowej. Mogę w odpowiedzi podawać różne uzasadnienia mojego roszczenia - okazać dowód osobisty, świadectwo urodzenia, znaleźć świadków, poddać się testowi na wykrywaczu kłamstw wszystkie te uzasadnienia mogą być jednak podane w wątpliwość. Jak powiada Wittgenstein, każdy łańcuch uzasadnień musi mieć swój kres (szpadel trafia na skałę) i wówczas muszę powiedzieć, że po prostu tak postępuję... (Wittgenstein, 2000). Sytuacja ta wydaje się absurdalna - nieracjonalna - i wskazuje na to, że czasem niepodawanie w wątpliwość roszczeń ważnościowych może być bardziej racjonalne niż podawanie ich w wątpliwość. Chodzi o to, że są sytuacje, w któ- 
rych przyjęcie pewnych oczywistości jest całkowicie racjonalne. W tym kontekście definiowanie racjonalności jako umiejętności uczestniczenia w grze racji wydaje się mocno problematyczne.

\section{Uwagi końcowe}

Na koniec chciałbym wskazać kilka punktów zbieżnych pomiędzy omawianymi koncepcjami, a także jawnych niezgodności. Podejmę cztery kluczowe dla dyskusji tematy: stosunku dyskursu do języka potocznego, rozumienia podmiotowości oraz świata społecznego, miejsca koncepcji dyskursu w szerszej orientacji metodologicznej. Zacznę od podstawowej dla mnie kwestii, czyli problemu stosunku dyskursu do języka potocznego czy codziennej komunikacji. Zarówno Foucault, jak i Habermas, nie są zainteresowani czymś, co można by nazwać „mową codzienną” czy „codzienną komunikacją”. Choć Foucault odrzuca porównanie swojego rozumienia wypowiedzi z koncepcją aktów mowy Austina i Searle’a (Foucault, 1977: 111-113), można zaryzykować stwierdzenie, że odrzuca je, ponieważ interesuje się wypowiedziami „poważniejszymi”, takimi, które przeszły pewien instytucjonalny test, tzn. w jakiś sposób „pretendują” do prawdy (Dreyfus, Rabinow, 1982: 45-47) (by nie powiedzieć: „wysuwają roszczenie...”). Nie znaczy to jednak, że Foucaulta interesują jedynie wypowiedzi naukowe, chodzi raczej o takie wypowiedzi, które stały się częścią szerszego dyskursu instytucjonalnego (na przykład przypadek Pierre’a Riviere’a - Foucault, 2002). Podobnie dla Habermasa - zwykła, codzienna rozmowa nie ma znaczenia, dopóki nie zostaną zakwestionowane wysuwane w niej roszczenia ważnościowe i uczestnicy nie zaczną podawać racji i argumentów w ich uzasadnieniu. Dyskurs naukowy jest zapewne dobrym przykładem funkcjonowania dyskursu, ale zapewne można sobie wyobrazić inne sytuacje, w których nasze wypowiedzi muszą być uzasadnione. Dla Laclau natomiast dyskurs ma dużo szersze znaczenie, gdyż uznaje on za niego każdą praktykę oznaczania. Dyskursem jest wszystko to, co posiada znaczenie, czyli w zasadzie całość tego, co społeczne. Można więc powiedzieć, że jego koncepcja jest najbardziej „demokratyczna”.

Wskazywałem już na podobieństwa w rozumieniu formacji dyskursywnej występujące u Laclau i Foucaulta. W podobny sposób można porównać ich koncepcje podmiotowości („pozycje podmiotowe”), w których uczestnictwo w dyskursie jest dla podmiotu procesem go konstytuującym. W późnych pracach Foucault kładzie jednak większy nacisk na podmiotowe wysiłki konstytuowania siebie wbrew dyskursowi („techniki siebie”, „troska o siebie”). Tutaj staje się 
bliższy Habermasowi, który przyjmuje Kantowską koncepcję racjonalnego i autonomicznego podmiotu.

Podobnie rozkładają się relacje między tymi trzema koncepcjami, jeśli chodzi o rozumienie świata społecznego czy też tego, co polityczne. Foucault i Laclau są przekonani o antagonistycznym/agonistycznym charakterze dyskursu oraz tego, co polityczne, gdzie zgoda lub porozumienie może być budowane tylko jako wynik gry hegemonicznej (Laclau) albo jest pewną fikcją (Foucault). Dla Habermasa zaś pojęcia porozumienia i zgody są podstawą norm moralnych i prawnych obowiązujących w społeczeństwie, a także normatywną podstawą krytyki.

$\mathrm{Na}$ koniec należy zaznaczyć wyraźne różnice pomiędzy wszystkimi trzema koncepcjami, dotyczące założeń metodologicznych. Dla Foucaulta dyskurs jest narzędziem metodologicznym służącym analizie historycznej. Foucault raczej ucieka więc od rozpatrywania dyskursu w kategoriach ontologicznych. Dla Laclau dyskurs stanowi zaś ontologiczną ramę walki o hegemonię, jest warunkiem tego, co społeczne. U Foucaulta ów motyw transcendentalny jest również obecny, jednakże służy on mu jedynie za genealogiczny krok w kierunku oporu przeciwko dominacji, mający ukazywać przygodność i historyczność konkretnej formacji władzy. U Habermasa natomiast dyskurs jest idealną, kontrfaktyczną sytuacją („sytuacja idealnej rozmowy”), pozwalającą legitymizować decyzje podjęte $\mathrm{w}$ debacie publicznej.

\section{Literatura}

Althusser L. (2009). W imię Marksa. Tłum. M. Herer. Warszawa.

Andersen N.A. (2003). Discursive Analytical Strategies: Understanding Foucault, Koselleck, Laclau, Luhmann. Bristol.

Ashenden S., Owen D. (eds.). (1999). Foucault Contra Habermas: Recasting the Dialogue between Genealogy and Critical Theory. London-Thousand Oaks-New Dehli.

Austin J.L. (1993). Mówienie i poznawanie. Tłum. B. Chwedeńczuk. Warszawa.

Bachelard G. (1949). Le rationalisme appliqué. Paris.

Bachelard G. (2002). Kształtowanie się umystu naukowego. Przyczynek do psychoanalizy wiedzy obiektywnej. Przeł. D. Leszczyński. Gdańsk.

Canguilhem G. (1957). La formation du concept de réflexe aux XVIIe et XVIIIe siècles. Paris. de Saussure F. (2002). Kurs językoznawstwa ogólnego. Przeł. K. Kasprzyk. Warszawa.

Derrida J. (2009). Struktura, znak i gra $w$ dyskursie nauk humanistycznych. Tłum. K. Kłosiński. [W:] L. Rasiński (red.). Język, dyskurs, społeczeństwo. Warszawa.

Dreyfus H.L., Rabinow P.K. (1982). Michel Foucault: Beyond Structuralism and Hermeneutics. Hempstead.

Foucault M. (1977). Archeologia wiedzy. Przeł. A. Siemek. Warszawa. 
Foucault M. (1990). Q'est-ce que la critique?. „Bulletin de la Société Française de Philosophie”, vol. LXXXIV.

Foucault M. (1994). Réponse à une question. [W:] M. Foucault, Dits et écrits: 1954-1988, t. I, éd. D. Defert, F. Ewald. Paris.

Foucault M. (2000a). Nietzsche, genealogia, historia. [W:] M. Foucault, Filozofia, historia, polityka. Wybór pism. Red. i tłum. D. Leszczyński, L. Rasiński. Warszawa-Wrocław.

Foucault M. (2000b). Strukturalizm i poststrukturalizm. [W:] M. Foucault, Filozofia, historia, polityka. Wybór pism. Red. i tłum. D. Leszczyński, L. Rasiński. Warszawa-Wrocław.

Foucault M. (2000c). Życie: doświadczenie i nauka. [W:] M. Foucault, Filozofia, historia, polityka. Wybór pism. Red. i tłum. D. Leszczyński, L. Rasiński. Warszawa-Wrocław.

Foucault M. (2002). Ja, Piotr Riviere, skorom już zaszlachtował moja matkę, moją siostrę i brata mojego... Tłum. T. Komendant, G. Wilczyński. Gdańsk.

Gramsci A. (1961). Nowoczesny książę. [W:] A. Gramsci. Pisma wybrane, t. I. Tłum. B. Sieroszewska. Warszawa.

Habermas J. (1982). A Reply to my Critics. [W:] J.B. Thompson, D. Held (eds.). Habermas: Critical Debates. Cambridge.

Habermas J. (1983). Niektóre trudności próby związania teorii z praktyką. Wprowadzenie do nowego wydania, [W:] J. Habermas. Teoria i praktyka. Wybór pism. Warszawa.

Habermas J. (1999). Teoria działania komunikacyjnego, t. I. Przeł. A.M. Kaniowski. Warszawa.

Habermas J. (2000a). Filozoficzny dyskurs nowoczesności. Przeł. M. Łukasiewicz. Kraków.

Habermas J. (2000b). Teoria działania komunikacyjnego, t. II. Przeł. A.M. Kaniowski. Warszawa.

Habermas J. (2004). Działanie komunikacyjne i detranscendentalizacja rozumu. Przeł. W. Lipnik. Warszawa.

Habermas J. (2015a). Discourse Ethics. [W:] J. Habermas, Moral Consciousness and Communicative Action. New York.

Habermas J. (2015b). Moral Consciousness and Communicative Action. New York.

Harris R. (1988). Language, Saussure and Wittgenstein. How to Play Games with Words. London-New York.

Jakobson R. (2009). Język i mówienie: kod i przekaz. [W:] L. Rasiński (red.), Język, dyskurs, społeczeństwo, Warszawa.

Kelly M. (ed.). (1994). Critique and Power: Recasting the Foucault/Habermas Debate. CambridgeLondon.

Laclau E. (1996). Emancipation(s). London-New York.

Laclau E. (1998). Dyskurs. [W:] R. Goodin, P. Pettit (red.). Przewodnik po wspótczesnej filozofii politycznej, tłum. C. Cieśliński i M. Poręba. Warszawa.

Laclau E., Mouffe Ch. (1990). Marxism without Appologies. [W:] E. Laclau, Ch. Mouffe. New Reflections on the Revolution of Our Time. London.

Laclau E., Mouffe Ch. (2007). Hegemonia i socjalistyczna strategia. Przyczynek do projektu radykalnej polityki demokratycznej. Tłum. S. Królak. Wrocław.

Leibniz G.W. (2001). Nowe rozważania dotyczące rozumu ludzkiego. Tłum. I. Dąmbska. Kęty.

Locke J. (1955). Rozważania dotyczące rozumu ludzkiego. Tłum. B. Gawecki, przekład przejrzał Cz. Znamierowski. Warszawa.

Platon (1990). Kratylos. Tłum. W. Stefański. Wrocław.

Stavrakakis Y. (1999). Lacan and the Political. London-New York. 
Taylor Ch. (2009). Teorie znaczenia. Tłum. A. Orzechowski, W. Jach. [W:] L. Rasiński (red.). Język, dyskurs, społeczeństwo. Warszawa.

Tully J. (2008,). Public Philosophy in a New Key: Volume 1, Democracy and Civic Freedom. Cambridge. Wittgenstein L. (1974). Philosophical Grammar. ed.R. Rhees. Trans. A. Kenny. Oxford.

Wittgenstein L. (1999). Niebieski i brązowy zeszyt. Szkice do Dociekań filozoficznych. Przeł. A. Lipszyc, Ł. Sommer. Warszawa.

Wittgenstein L. (2000). Dociekania filozoficzne. Przeł. B. Wolniewicz. Warszawa. 